\title{
Social Myth in Modern Society
}

\author{
Irina Ponizovkina \\ Department of Philosophy \\ Plekhanov Russian University of Economics \\ Moscow, Russia \\ E-mail: irina-ponizovkin@mail.ru
}

\begin{abstract}
The article is dedicated to the social mythmaking problem which became relevant again in the $21^{\text {st }}$ century due to the processes of globalization and informatization, the new geopolytical balance of power and the mixed political situation. This article considers the myth as a specific way of the surrounding reality exploration, rooted in far past but manifesting its phenomenal survivability and revivability. The author focuses on the essential features of the social myth which remain in demand under modern conditions. The article also analyzes the features of the modern age which lead to extension of the functional field of the mythological consciousness. The author is guided by the huge potential of the myth as a way of the goal-directed impact on social consciousness. At that, the ambivalence of the myth and its ability to play the historically different roles in modern society is emphasized. The author is sure that without mastering the mechanism and the ways of functioning of the social myth, as well as without seizing the point of this phenomenon and the nature of the secondary ideological myth-making, it is impossible to struggle effectively with this phenomenon or manage this process successfully. Thus, this research task, on one hand, is the theoretical solution of the problem of mythological invariant and the modern transformations of the myth and, on the other hand, the identification of the practical relevance of this topic to manage the mass consciousness processes in the sociopolitical and ideological areas.
\end{abstract}

Keywords-social myth; myth-making; mythological consciousness; mass consciousness; mythologem; modern society; consciousness management

\section{INTRODUCTION}

Mythology is one of the most crucial sociocultural phenomena the study and analysis of which offer a clue to comprehension of many events of the spiritual life of society at different levels of its development. In the $21^{\text {st }}$ century, the problem of social myth-making became relevant again due to the processes of globalization and informatization, the new geopolytical balance of power and the mixed political situation, as well as discovered some new aspects of its impact on historical development of society.

In the modern age of all-round globalization, the truth of views of the Russian cosmic philosophers of the late $19^{\text {th }}-$ early $20^{\text {th }}$ century is being confirmed that Man must take responsibility for the 'spiritualization' of the Earth and the Universe. In the new millenium, the humanity, finally, is getting on to the fact that the global problems (for example, the environmental ones) of nowadays cannot be solved by the formally scientific methods only. The nature must be seen hominized, 'animate', to feel emotionally like its integral part. It is necessary to build the world 'with a human face'. An idea suggests itself as for a new level ressurection of the mythological world perception by the ancestor feeling not only like a casual observer of the processes occurring in the world around, but their direct participant, on the certain actions of whom it depends on whether tomorrow comes or not ('all on me' and 'me on all').

In the political and moral-spiritual areas, the extension of the functional field of the modern mythology is stimulated considerably by technical capabilities and the global mass media network existence, as well as the information and ideological war build-up worldwide. In this respect, the latent off-rational attitudes of consciousness are quite effective. The social earthquakes, the information space battle between countries and the tragic political events (acts of terrorism, color revolutions, local wars, etc.) have demonstrated clearly that ignoring or underestimating the role of such moments in the socium is not only antiscientific but also dangerous.

As practice has shown, it is not easy to get rid of the established myths, since they are a unique and, in many cases - necessary way of mastering reality by the mass subject which has had the existing mechanism of functioning for centuries. Here emerges a natural question: Should we always get rid of myths? Anyway, without mastering the mechanism and the ways of functioning of the social myth, as well as without seizing the point of this phenomenon and the nature of the secondary ideological myth-making, it is impossible to manage this process successfully. This article makes it a point to: 1) consider the traditional problem of fuzziness of definitions, related to the concept of 'myth' itself; 2) thereupon analyze the essence and the ways of functioning of the modern social myth; 3) pay special attention to the problem of mythological invariant and the ambiguous opportunities for myth's impact on modern society. It should be noted that, as of today, the mass consciousness process management in the sociopolitical and ideological fields, as well as the determination of negative consequences of the social myth-making, are a real problem to politicians, ideologists and authorities, in general, both for the domestic policies of countries and on the international stage. An onerous and more usually-a superficially metaphorical interpretation of the concept of 'myth' will not work here. We should be guided by a deeper and more 
comprehensive view of this phenomenon to be formed and updated on the basis of a synthesis of achievements of various disciplines in this area.

\section{CASE STUDY}

A currently dominating allegoric interpretation of myths takes its origin from the ancient Greek philosophy. By the first half of the $18^{\text {th }}$ century, it was complemented by a deeper insight into the myth by an Italian scholar G. Vico who had forestalled the future mainstreams for mythological studies [16]. The Enlighted Frenchs (D. Diderot, F. Voltaire, Ch.-L. Montesquieu, B. Fontenelle and others) - influential to the social thought of the subsequent centuries - had considered the myth as a superstition, a product of ignorance and deception. It should also be noted that such interpretation of the myth had become definitive in the years ahead. F. Schelling had overcomed the traditional allegoric interpretation of the myth in favor of the symbolic one. He insisted on understanding the myth 'from inside', i.e., as an independent world to be understood under its internal laws [12]. Such interpretation of the myth has not lost its meaning by today...

A truly scientific understanding of mythology began in the second half of the $19^{\text {th }}$ century. E. Tylor (the anthropological or evolutionistic school) identified the early mythology with the prehistorical gnoceology, which, along with the scientific knowledge development, moved into the realm of relics and superstitions and came down to a naïve, prescientific explanation of the outside world [14]. J. Frazer considered the myth just as a goetic or magical ritual pattern, and the magic itself - as the most ancient versatile form of worldview. The views of B. Malinoskiy (the functional school), who had denied the theoretical role of the myth and proved the functional meaning of mythology as an unwritten code of primitive man, are quite interesting.

The research where the primary focus is on identifying the specific nature of mythological consciousness, such as the D. Durkheim theory of the collective experience expression in the myth and the postulate of the imperative, prelogical nature of primitive thinking; the L. Lévy-Bruhl (the French sociological school) law of participation; the E. Cassirer symbolic theory - are of great significance. The works by C. Jung, who had connected myths with the Collective Unconscious through the theory of archetypes, are still relevant. The research by a French ethnologist C. LévyStrauss, a Romanian scholar in culture studies M. Eliade, a French semiologist R. Barthes, as well as a German philosopher and methodologist K. Hübner, who had applied the methods and results of the modern philosophy of science to mythology, may also be noted.

The Russian 'philosophers of All-Unity' (V. Solovjov, S. Bulgakov, P. Florenskiy and others) had appealed to mythology, when analyzing the metaphilosophical problems to revive its significance as the sample of syncretical world perception and attitude to reality.

In the Soviet science, myths had mostly been studied by ethnographic historians (S. Tokarev, V. Iordanskiy and others), philologists (M. Steblin-Kamenskiy, Y. Meletinskiy, etc.), structural linguists attempting to reconstruct various semantic layers of the mythological worldview (V. Toporov and V. Ivanov), whose creative work by the depth of conclusions is akin to the philosophical analysis. The creative work of A. Losev, different from the traditional Soviet school, is of some interest, too. In his work 'Dialectic of the Myth' he analyzes the essence of the myth, placing it into the thick of the historical and social processes [8]. At that stage, the interest of political scientists and the ideological front representatives in the content-related constituent of the modern myth-making is expressed more often. Each of the proposed approaches allows for penetrating into its own area of the problem space of mythological consciousness and, therefore, helps to create a certain phenomenon model.

Thus, a several approaches to this phenomenon were created in the research literature, such as: (1) myth as a 'historical site' on which the archaic society representatives' ways of living and thinking are reconstructed; (2) myth as a kind of worldview, typical to primitive societies; (3) myth as an illusory perception of reality by ancient people; (4) myth as a specific way of mastering reality; (5) myth as a fabrication, deception, fiction and phantom of imagination. In the first three meanings, the myth is considered and studied as a historically transient phenomenon. To present the myth so timebound is just not fair. The interpretation of the myth as a 'fiction' or a 'fantasy' is also giving rise to doubt, despite being quite popular today, however, rather having some metaphoric, figurative meaning.

A semantic uncertainty and a careless use of this concept in literature and mass media embarass the insight into the essence of this phenomenon, often leaving the researchers of a solid empyric material at the level of 'descriptiveness'. "The word 'myth', - R. Guardini wrote in 1945, - is among those we have been using too often in recent years, sometimes inappropriately and, therefore, they need to be explained" $[5,132-165]$. The thinker's words are still relevant today...

In this case, we will be interested in the myth as a specific way of mastering reality, tracing its roots to the ancient times but demonstrating its phenomenal survivability and revivability. Here, mythology raises even more questions than provides answers...

\section{THE MYTH'S REVIVABILITY}

Why is the myth able to revive again and again, and where is the origin of such ability? It seems to me that mythological consciousness has never disappeared from the deep layers of upcoming cultures, but accompanied humanity throughout the course of its history, just changing the strength of manifestation and the vectors of influence on social processes. Mythology is linked genetically with the later historical types of worldview (religion, philosophy and even science) and is present in a 'coiled' latent state in a variety of the modern society's spiritual life phenomena (for example, in the form of a political ideology or the historical national myth-making). It is not for nothing that a Russian philosopher A. Losev, analyzing the essence of the myth, characterizes it as a 'universal quality of culture' [8]. 
The myth's abilities to keep alive are related to its features, relevant to the modern situation. The revolutionary achievements of science, a dizzy technological progress, a stubborn race of researchers for the phantom of objective reality, a sublime negligence of all the irrationally-subjective as, allegedly, 'false' - all this can make us feel superior over the nature for a while, but cannot save us from ourselves. By the late $20^{\text {th }}$ - early $21^{\text {st }}$ century, the feeling of mutual dependency and concern, an uncertain sensation of the world ill-being and instability, as well as the human existence fragility, have been deepening; and the faith and the opportunities for comprehension of the logic of events in the dynamic world, which is different by an extreme mobility of the ties and dominants - have been getting weaker.

The scales of the scientific knowledge of reality (despite all its achievements) are too far below the grand, diverse and real involvement of Man in this reality. We cannot but agree with M. Horkheimer that the modern mind is getting more and more instrumental - unable to set the overarching socially strategic and sense-making aims related to the existential selection of values [6]. The immediate view of life and mentality in this case appear to be immeasurably richer, wider and sometimes deeper than the rationally logical methods. Such out-of-rational knowledge phenomena as faith, intuition, practical everyday knowledge, emotional perception of reality are all becoming a source of a unique mean of reconciliation with reality. Including through updating the mythological mass consciousness, too.

Let us elaborate on the point of the essence and those features of mythological consciousness in its authentic but not metaphorical meaning which makes its specification possible among other mass consciousness phenomena, as well as the solution of the problem of mythological invariant and the modern world transformations of the myth. Myth is an intrinsically dual sociocultural phenomenon that allows Man (mass subject) for being directly, naturally and continuously included in a contradictory tissue of the true relations and rooting into various ontological layers of the Universe, preserving, at that, its own integrity and the integrity of the perceptible existence. It is such a state of mass consciousness which allows for living the outside world like your own - so close and lived-in. Man still lives here today. He is active in mastering reality, trying to catch a sustainable abundance of its properties and ties by those means and ways available and matching. At that, the subject cannot understand and recognize the illusory nature of its consciousness. The myth is not so much aimed at explanation, but at a direct adaptation to the conditions and various situations of existence.

The effectiveness and efficiency of such mastering are primarily related to the mythological consciousness syncretism. This is the inseparability in the mythical image of the idea-image, the sensual-visual form, the action (a motivating factor) and the emotional constituent. This feature is supported by a specific symbolic activity, which is specifically a visual embodiment of those or other ideas and meanings by pointing "to unknown objects by any clear and quite known structure" [9], which makes any situation mentally conceivable. It is not surprising how often during the current information war not 'bare' facts but cartoons and photos are used, addressing not to the mind but the heart of the mass consumer of information.

The symbol in the myth is distinguished by an inexhaustible semantic fullness. Thus, primitive man once mastered the world by the semantically-emotionallyassociative rows with no clear boundaries. Such spontaneous mastering assumes not the establishment of logical connections and regularities, but an intuitive 'grasp' of the situation, in general, a readiness for eventualities. Alongside, any seeming petty and random but visible and emotionallycoloured part can be the center of attention, become the embodiment of such integral unity in the chain of associations. Let us take for instance, a demonstration of any of items and artifacts to confirm political ideas. The mass subject perceives the impressions of the surrounding reality not through the prism of suspended critical reasoning, but directly and sympathetically, if they are included in the circle next to the interests and the scope of his emotional experience. This characteristic of myth-making is still in demand in the present-day conditions.

Today's social system is in an extremely volatile state where even small deviations may induce an inadequately strong, avalanche-type or a chain reaction the consequences of which (especially, humanitarian) are difficult to predict. The human community of the post-modernity era represents a 'mosaic' formation, constantly changing the dominant points and interdependencies. That is why to such researcher as Z. Bauman the contemporary world is a 'flowing modernity', erratic and fragmented, where "the soil itself moves" (as F. Emery had put it) [3, 249]. A. Giddens, in his book with the eloquent title: 'Runaway World: How Globalization Is Reshaping Our Lives' sees reality constantly eluding from the hands and tries to express the feelings of unpredictability, that is experienced by many of us living in an era of rapid changes $[5,13]$. A very accurate metaphorical definition was coined by a well-known specialist in Management, Professor P. Vaill: today humanity is 'a world of chaotic changes, 'constantly bubbling water' [15]. In the context of complex and uncertain dynamic systems people are forced to take decisions and act in no longer "causal chains', but 'causal networks' not always belonged to human mind. Like many millennia ago, Man again lives in anticipation of metamorphoses and adapts to the situation using myth-making, creating the archetypal images of the Savior, the eschatological subjects, ignoring the contradictions, etc.

The tragic social cataclysms of the $20^{\text {th }}$ and early $21^{\text {st }}$ century - revolutions, local conflicts and world wars, environmental disasters, information attacks, economic and political crises, accompanied by forced migrations of population and the violent breakdown of their habitual way of life, have shown that social myths are becoming a source of the enormous vitality (both constructive and destructive). "The Irrational... is becoming the basic condition for human existence. At the outset, hope which supports us in our aspirations, doubts and even contrary to the logic of rational; intuition... provides us with the ability to act where we, from the point of view of mind and rationalism, should refuse, 
inner conviction... acting often in defiance of the obvious and logical arguments...; the ability to association of barely perceptible signals, subconscious or unconscious assessment of their value - these are some examples of phenomena, very important in the life and activity that are necessary to add sense to life and activity" [13].

\section{SOCIAL MYTH AND MASS CONSCIOUSNESS}

There are the relations of interdependence between mythological and mass consciousness: the myth is created and maintained by mass consciousness, and consciousness relies on the myth and is nourished by it. The modern era is a time of the rapid flow of mass movements and mass communities as active subjects of sociopolitical and historical processes. Modern societies are the societies of media, mass movements, mass culture and consumer goods which lost a specific individual by becoming a 'zero-subject', a part of some community (as here one cannot but mention ancient tribal man).

The mass subject is rooted in the currently relevant layers of existence which pose some cultural-historical, social framework in thinking and perception of reality. This transform mass consciousness on the fertile ground on which the mythological tree grows.

Mass consciousness is not prepared to perceive drastic changes in the internal and external existence, when there has been a surge of emotions and moods. Like in the ancient myth, the spatio-temporal framework shifts: irreversible 'time-history' disappears, and the sensual-emotional (mythological) attitude to 'one's' time intensifies. The future, in the situations of all kinds of disasters and catastrophes, becomes the present, and the past (and its errors) pops up in the most unexpected forms. A social protection - the social illusions - is activated. Therefore, the transitional historical era is always filled with all kinds of phobias, historical myths, national legends, etc.

The use of different types of illusions - religious ideas, social utopias, images, stereotypes, etc. - for myth-making, intended for the political and other purposes, occurs in hidden form $[10 ; 11]$. Thus, being the main factor of selfdetermination, self-fulfillment of Man and mankind, consciousness can become a tool of the disorientation of people. Public consciousness, like two-faced Janus, sometimes acts as a wise counselor, then - as a treacherous deceiver enticing people into the world of lifeless ideas and dangerous dreams. The relevance of theoretical comprehension of this topic increases alongside with the further development of communication tools and mass media.

A sociopsychological basis of the myth should be sought in other features of the mass subject (crowds, online community, team, etc.) - sensitivity, the phenomena of collective emotional contagion, auto-emulation/mimetic response and complete suggestion, as well as in current law of inertia (any social movement, once having developed tends to spreading), the law of compensation (replacement), when society cannot comprehend a new trend or fast changing information $[1 ; 2]$.

\section{FunCTIONING OF THE MODERN MYTH-MAKING}

As we can see, most of pre-requisites for the modern myth-making, seeming to be a condition for the primitive mythologization - on the contrary, are similar by the essence of 'contradiction', either. Today, the functional field of myth-making has not only narrowed, but also the demand is increasing for a present-day 'zero subject' in the myth as a means to discover the environment, belonging to a certain community, feeling of protection, emotional comfort, to discover spiritual firmness and, finally, to recover the sense and integrity of existence and to find their place in the surrounding reality.

Today, the global communication space is becoming an impetuous information environment where ever greater, and sometimes a decisive role is acquired by the information mass-media technologies. Largely, it is thanks to the state-ofthe-art communication tools and mass media, the concept of 'global village' arises. The Internet communications are undoubtedly, on one hand, a catalyst factor of the information space globalization and democratization, but, on the other hand, contain a risk of oversupply and unreliability of information, in front of which even the rationally adjusted tactics fails. "... Only a few can remember", - P. Vaill says, that our psyche approaches to a certain red line, like in a steam boiler, so to a state, where it is impossible to master the situation [15, 16]. In this case, the ancient, time-tested mechanisms of myth-making enrooted in the depths of mass consciousness get on the ground...

And again, the residents of the global village, like the ancient tribal man, feel involved directly as co-participants in the situation around them - due to the accessibility, availability and visualization of information. The information flow is turning into chaos and in this case it is impossible to refuse any complexity and pass over to a psychological defense - perceptive simplicity according to the principle of such ancient binary oppositions as 'blackwhite', 'friend-alien', etc. As a result, we have the destroying of cultural monuments, the unequivocal and unfounded accusations of foreign cultures and nations, the striving for the religious and political demarcation... At best, a simplified look at other cultures may result in sizing up other crops under one's own standards. While sometimes mistified and simulative nature of ideas remains unnoticed to the subject.

Not the last role in creating the persistent mythological images is played by the visualization of information using a variety of multimedia, video series, based on the usual archetypes (the Hero, the Savior, the Universal Evil, the Victim, etc.). Under the influence of audiovisual technologies the myth-making channels are becoming more diverse and compelling.

Alongside with the strengthened mythological perception, no rational arguments or indications to contradictions are able to shake confidence in the truthfulness of the current picture. Mythological consciousness is of notoriously noncritical nature and allows the subject for fitting organically into any, most difficult and confusing situation or ambiguous political relationships, while maintaining their own integrity 
and the integrity of the perceived existence. And if the social myth is successfully performing this basic task, then the contradictions and inconsistencies of mythological ideas are ignored.

Social myths also act as an effective way to mobilize community. Therefore, the view of the indivisibility of mythological and political consciousness is quite common. Lévi-Strauss noticed that nothing is so reminiscent of mythology, as political ideology [7]. There are grounds for it.

The sociopolitical reality is the endeavour of the immediate human interests. The political myths often grow out historically of the need to adapt and master a complex, ambiguous and often contradictory political reality and 'translates' directly into mass consciousness. This is the awesome power of a genuine myth capable of forming its mythological illusory reality (as in Nazi Germany or Stalin's Russia), indistinguishable from reality to the subject. The political myths are often based on the ideology of the people's (countries') past as a kind of sample. This is a typical feature of mythological consciousness because understanding the origin of the phenomenon means understanding its 'reasons', giving answers to many fundamental questions of the people's self-identification. The historical characters are also mythologized, which makes them alive and giving rise to a sense of involvement, empathy or pride.

The traditional mythical images often become the basis for the formation of a new political myth: for example, in a crisis social situation the ancient myth of the Savior is 'tried' on a particular politician, and he takes the shape of a mythological hero capable to lead the country to 'the shining path' of all the misfortunes and disasters. This 'hero' is forgiven much by mass consciousness, and his contradictory character is not noticed at all. Or, on the contrary, a political leader is ascribed to the image of the Universal Evil and, thus, they try to take him/her out of the global political game. This mythological 'blindness' of the mass subject sometimes comes at a price to it. In this case, it is necessary to bear in mind that in political consciousness the mythological one often takes shapes of the secondary myth-making and pseudo-myths, where only the mass consciousness' digestion of those ready works made by skilful masters-political technologists takes place.

In the sociopolitical myths, the archetypical urlogic of oppositions is quite effective. The 'source of evil' in any situation is usually found quickly and formed into a corresponding myth (of the 'Evil Empire' during the cold war, "about the growth of the class struggle" in postrevolutionary Russia, "on the insidiousness of ill-wishers and enemies", etc.) that replaces the search for causal relationships, quite cumbersome and often inaccessible to mass consciousness. And the sensual-visual, emotionalsaturated images are more convincing to mass consciousness than logical arguments.

Myth-making is ambivalent and not always means lies, misrepresentation and the creation fantastic images - so far from reality. The myth has always played and plays a mixed role in the history of mankind - both negative and progressive. Today, there is a growing need for the sociocultural myth as a mean of the national selfidentification, a way to acquire its cultural niche in a complex contradictory modern world. Such spiritually developing myths based, like in ancient times, on a sympathic attitude to the surrounding world and other cultures, capable to organize the chaotic 'bustling' worldview, are needed to every nation because they make it an organic part of the Universum. A rough attack on the social myth's symbols, an artificial destruction of so far formed images lead to the chaotic state of the spirit of society, cultural devastation, loss of raison d'être and disorientation.

Today, social myth continues meeting successfully the challenges of time, surprising by the efficiency of adaptation and the validity of approaches. However, one should learn to use the potential of the myth for the benefit of mankind and overcome the negative effects of mythmaking effectively.

\section{CONCLUSION}

In modern society, despite all the attempts to rationalize human activity and calls to get rid of social illusions, the functional field of mythological consciousness is expanding. The myth, being the oldest manifestation of public consciousness, is amazing by its phenomenal ability to revive, sometimes in the most unexpected forms, modifications and situations. There is also a latent ideological exploitation of the results of the secondary social myth-making. The struggle for the information space between the countries and the recent international political developments have clearly showed that it is not only irrational but also dangerous to ignore or underestimate the role of extra-rational factors in society, primarily of mythological consciousness. Social myth-making is ambivalent: it performs the functions in society which are often controversial by the social and epistemological consequences. On closer examination, the myth strikes with its internal consistency and ability to fit Man harmoniously into its view of the surrounding existence - into any specific situation. Here lies an enormous potential of the myth - not only as a way of sensual (affective) mastering of reality, but also targeting mass consciousness. The relevance of the theoretical comprehension of this topic is increasing and will increase in parallel to further development of communication tools and mass media.

An important task is to realize social myth as an immanent active element of the contemporary mass consciousness, learn to identify and take into account the nature of functioning of this phenomenon, basing on this standpoint. At that - to get rid of the arrogant attitude to the myth and perceive it as an important factor enriching the spiritual experience of humanity. And how humanity will dispose of the unspent potential of the myth - depends on us...

\section{REFERENCES}

[1] Bekhterev, V.M., "Collective reflexology”, Petrograd: Kolos, 1921.

[2] Bekhterev, V.M., "Suggestion and its role in public life", St. Petersburg: K.L.Rikkera edition, 1908. 
[3] Emery, F. E., "Systems thinking: selected readings", Penguin, 1969, $398 \mathrm{p}$.

[4] Giddens A., "Runaway World: How Globalization Is Reshaping Our Lives", Moscow: "The whole world", 2004, 120 p.

[5] Guardini, R., "The Savior in the myth, the revelation and politics. Theological and political reflection", in Philosophy of Science, 2 (1992), pp. 132-165

[6] Horkheimer, M., "Critique of Instrumental Reason", N.Y. Continuum, 1985, $163 \mathrm{p}$.

[7] Levi-Strauss, C., "Structural Anthropology", 1958 publ. Allen Lane, The Penguin Press., 1968.

[8] Losev, A.F., "The Dialectics of Myth", Moscow, Vol author, 1930

[9] Losev, A.F., "The Problem of the Symbol and the Art of Realism", Moscow: Art, 1976, $367 \mathrm{p}$

[10] Ponizovkina I.F., "Myth as a phenomenon of the illusory consciousness": Dissertation, Moscow, 1989, 189 p.

[11] Ponizovkina, I.F., "Illusory consciousness and society": Monograph, Moscow: MIRBIS, 2012, $190 \mathrm{p}$.

[12] Schelling, F. W. J., "Historical-critical Introduction to the Philosophy of Mythology" (SUNY series in Contemporary Continental Philosophy), State University of New York Press, June 5, 2008, 264 p.

[13] Szczepanski, J., "Human Affairs", in Gitulyar, M.P., Filippov, B.A., "Jan Szczepanski about man and society": collection of articles, USSR Academy of Sciences, Institute of Scientific. Information on Social Sciences, Moscow, 1990, p. 7-41.

[14] Taylor E.B., "Primitive Culture", Cambridge University Press, 2010, $426 \mathrm{p}$.

[15] Vaill P. "Managing as a Performing Art: New Ideas for a World of Chaotic Change", Wiley, 1991, $264 \mathrm{p}$.

[16] Vico, G., "Foundations of the new science of the general nature of nations", Leningrad: Publishing house "Fiction", 1940, 619 p. 